\title{
INCONSISTENT GROWTH PROMOTION OF CABBAGE AND LETTUCE FROM TRICHODERMA ISOLATES
}

\author{
N. RABEENDRAN, D.J. MOOT, E.E. JONES \\ and A. STEWART
}

\begin{abstract}
Soil, Plant and Ecological Sciences Division, P O Box 84, Lincoln University, Canterbury, New Zealand
\end{abstract}

\begin{abstract}
Trichoderma isolates were evaluated for growth promotion effects on cabbage seedlings (Brassica oleracea L.) in glasshouse trials. Dipping transplants in spore suspensions $\left(10^{7}\right.$ conidia/ml $)$ of $T$. longipile (6Sr4 and 3Sr4-2) and T. tomentosum $(5 \mathrm{Sr} 2-2)$ increased $(\mathrm{P}<0.05)$ leaf area $(58-71 \%)$, shoot dry weight (91-102\%) and root dry weight (100$158 \%$ ) compared with the untreated control in one trial but not in a second. In a field trial, yield of lettuce (Lactuca sativa L.) treated with T. longipile $6 \mathrm{Sr} 4$ was also increased.
\end{abstract}

Keywords: cabbage, lettuce, growth promotion, Trichoderma longipile, T. tomentosum.

\section{INTRODUCTION}

In addition to their biocontrol activities, Trichoderma spp. have been reported to promote plant growth. Possible explanations of this phenomenon include: control of minor pathogens leading to stronger root growth and nutrient uptake (Ousley et al. 1993), secretion of plant growth regulatory factors such as phytohormones (Windham et al. 1986; Chang et al. 1986; Baker 1988) and release of soil nutrients and minerals by increased saprophytic activity of Trichoderma in the soil (Ousley et al. 1994a).

In the present study, Trichoderma isolates which had shown biocontrol activity against Sclerotinia on cabbage, were evaluated for their effects on leaf area and shoot and root dry weights of cabbage seedlings in two glasshouse trials. Trichoderma longipile $6 \mathrm{Sr} 4$ was also tested on lettuce in a field trial.

\section{Preparation of fungal inoculum}

\section{METHODS}

Trichoderma longipile isolates $6 \mathrm{Sr} 4,3 \mathrm{Sr} 4-2,8 \mathrm{Sr} 4-2, T$. virens $\mathrm{GV} 4$ and T. tomentosum 5Sr2-2 were grown on oatmeal agar (33 g/litre), T. virens B19 and T. longipile S1BYG were grown on potato dextrose agar (PDA, $39 \mathrm{~g} / \mathrm{litre}$ ) and incubated for 21 days at $20^{\circ} \mathrm{C}$ under a $12 \mathrm{~h}$ light (irradiance $1.05 \mathrm{~W} / \mathrm{m}^{2}$ ) $/ 12 \mathrm{~h}$ dark regime. Conidial suspensions $(100 \mathrm{ml})$ of each isolate were obtained by flooding plates with $0.2 \%(\mathrm{v} / \mathrm{v})$ Triton X-100 (BDH Ltd., UK) in sterile distilled water (SDW) and the concentration of conidia was adjusted to $5 \times 10^{7}$ spores $/ \mathrm{ml}$.

\section{Cabbage glasshouse trial 1}

Cabbage seeds (Brassica oleracea var. Leprechaun mini) were grown in germination trays containing standard potting mix for 28 days. Roots of seedlings were then immersed in conidial suspensions of each isolate $(100 \mathrm{ml})$ for $30 \mathrm{~min}$ before transplanting into $125 \mathrm{~mm}$ diameter pots containing potting mix $(80 \%$ composted bark; $20 \%$ sand; $2 \mathrm{~kg} / \mathrm{m}^{3} \mathrm{~N}: \mathrm{P}: \mathrm{K}(15: 4.8: 10.8) ; 4 \mathrm{~kg} / \mathrm{m}^{3}$ dolamite). The untreated control was $0.2 \%$ Triton $\mathrm{X}-100$ in SDW. There were seven fungal treatments and one 
untreated control. The experiment was a randomized complete block design with 10 replicate blocks, with one plant per treatment per block. The glasshouse experiment ran for 42 days. The ambient air temperature in the glasshouse ranged from 5.4 to $46.6^{\circ} \mathrm{C}$ with a mean of $17.7 \pm 7.5^{\circ} \mathrm{C}$. Total growing degree days $\left({ }^{\circ} \mathrm{Cd}\right)$ accumulated 28 days after planting (DAP), were $498^{\circ} \mathrm{Cd}$ (above a base temperature of $0^{\circ} \mathrm{C}$ ). A tube solarimeter was used to determine the percentage of shade in the glasshouse. Total solar radiation inside the glasshouse for $28 \mathrm{DAP}$ was $173 \mathrm{MJ} / \mathrm{m}^{2}$.

At 28 and 42 DAP, leaf area of five randomly selected plants in each treatment was measured. Washed roots, leaves and shoots were then dried to constant weight. Variables were analysed using ANOVA (SAS Institute Inc. 1989) and treatment means were separated using Fisher's protected LSD test (FLSD).

\section{Cabbage glasshouse trial 2}

Treatments, measurements and statistical analyses used were as described for trial 1 with the exception that there were two plants per treatment per replicate block. The glasshouse temperature ranged from 7.5 to $54.9^{\circ} \mathrm{C}$ with a mean of $21.1 \pm 7^{\circ} \mathrm{C}$ over the 28 days of the trial. Total growing degree days were $561^{\circ} \mathrm{Cd}$ and total solar radiation inside the glasshouse was $410 \mathrm{MJ} / \mathrm{m}^{2}$.

\section{Lettuce field trial}

A conidium suspension of $T$. longipile $6 \mathrm{Sr} 4\left(450 \mathrm{ml}\right.$ of $10^{7}$ conidia/ml) was incorporated into $4.5 \mathrm{~kg}$ of potting mix to give a concentration of $10^{6}$ conidia/g potting mix. Germination trays each consisting of 135 cells $(30 \mathrm{ml}$ volume/cell $)$ were filled with inoculated potting mix. Non-infested potting mix served as the experimental control. Lettuce seeds (Lactuca sativa cv. Yates lake) were sown into each cell and grown in the glasshouse for 28 days at $21^{\circ} \mathrm{C}$.

A field site at Lincoln University was prepared using conventional cultivation and the trial ran for 9 weeks. The design was a randomised complete block with two treatments and four replicates. Each block consisted of two $1 \mathrm{~m}^{2}$ plots $(25$ plants at $0.2 \times 0.2 \mathrm{~m}$ spacing) to which the two treatments (untreated control or T. longipile $6 \mathrm{Sr} 4$ inoculated to transplant potting mix) were applied. Plants were watered using an overhead sprinkler system through to harvest. For the first 28 days of the trial the mean ambient temperature was $16.6^{\circ} \mathrm{C}$ (range $12.8-21.7^{\circ} \mathrm{C}$ ), the growing degree days were $480^{\circ} \mathrm{Cd}$ and total solar radiation was $637 \mathrm{MJ} / \mathrm{m}^{2}$.

Mean fresh weight of harvestable head was recorded and data analysed using t-tests (SAS Institute Inc. 1989).

\section{Cabbage glasshouse trial 1}

\section{RESULTS}

Three isolates of $T$. longipile $(6 \mathrm{Sr} 4,8 \mathrm{Sr} 4-2,3 \mathrm{Sr} 4-2)$ and $T$. tomentosum $5 \mathrm{Sr} 2-2$ increased $(\mathrm{P}<0.05)$ leaf area by $71,32,58$ and $71 \%$, respectively compared with the untreated control at 28 DAP (Table 1). Trichoderma longipile (6Sr4, 3Sr4-2) and $T$. tomentosum $(5 \mathrm{Sr} 2-2)$ also increased $(\mathrm{P}<0.05)$ shoot dry weight by 94,91 and $102 \%$ and root weight by 142,100 and $158 \%$ respectively, compared with the untreated control. There was no effect $(\mathrm{P}>0.05)$ of fungal treatments on shoot:root ratio (4.9-5.9) compared with the untreated control (6.1) and growth promotion was not apparent at 42 DAP.

\section{Cabbage glasshouse trial 2}

Mean leaf area and shoot and root dry weights of cabbage at 28 DAP in control plots were 7.1, 3.8 and 0.5. Higher values for leaf area, shoot and root dry weight were recorded for T. longipile $6 \mathrm{Sr} 4-2$ and $T$. tomentosum $5 \mathrm{Sr} 2-2$ but these were not different $(\mathrm{P}>0.05)$ to those for the untreated control plants. There was no effect $(\mathrm{P}>0.05)$ of fungal treatment on any plant parameter at $28 \mathrm{DAP}$.

\section{Lettuce field trial}

Mean weight of harvestable heads was greater $(\mathrm{P}<0.05)$ for $T$. longipile $6 \mathrm{Sr} 4$ treated plots $(4.1 \mathrm{~kg})$ than for untreated plots $(2.9 \mathrm{~kg})$. 
TABLE 1: Mean leaf area, shoot and root dry weights (dry wt.) of cabbage plants for different fungal treatments at 28 and 42 days after planting.

\begin{tabular}{|c|c|c|c|c|c|c|}
\hline \multirow[b]{2}{*}{ Treatment } & \multirow[b]{2}{*}{$\begin{array}{l}\text { Leaf area } \\
\text { area } \\
\left(\mathrm{x} 10^{-2} \mathrm{~m}^{2}\right)\end{array}$} & \multicolumn{2}{|c|}{28 days after planting } & \multirow[b]{2}{*}{$\begin{array}{l}\text { Shoot: } \\
\text { root } \\
\text { ratio }\end{array}$} & \multicolumn{2}{|c|}{42 days after planting } \\
\hline & & $\begin{array}{l}\text { Shoot dry wt. } \\
\text { dry wt. } \\
\text { (g) }\end{array}$ & $\begin{array}{l}\text { Root dry wt. } \\
\text { dry wt. } \\
\text { (g) }\end{array}$ & & $\begin{array}{l}\text { Shoot } \\
\text { dry wt. } \\
(\mathrm{g})\end{array}$ & $\begin{array}{l}\text { Root } \\
\text { dry wt. } \\
(\mathrm{g})\end{array}$ \\
\hline $\begin{array}{r}\text { Untre } \\
\text { cont }\end{array}$ & $3.1 \pm 0.5 \mathrm{bc}^{1}$ & $1.16 \pm 0.3 \mathrm{~d}$ & $0.19 \pm 0.04 \mathrm{~d}$ & 6.1 & $6.51 \pm 0.3$ & $0.76 \pm 0.13$ \\
\hline $\begin{array}{l}\text { T. longipile } \\
6 \mathrm{Sr} 4\end{array}$ & $5.3 \pm 0.7$ a & $2.25 \pm 0.3 \mathrm{ab}$ & $0.46 \pm 0.08 \mathrm{ab}$ & 4.9 & $5.69 \pm 0.5$ & $0.89 \pm 0.06$ \\
\hline $\begin{array}{l}\text { T. longipile } \\
8 \mathrm{Sr} 4-2\end{array}$ & $4.1 \pm 0.3 \mathrm{a}$ & $1.63 \pm 0.2 \mathrm{abcd}$ & $0.32 \pm 0.05$ abcd & 5.1 & $5.51 \pm 0.6$ & $0.65 \pm 0.12$ \\
\hline $\begin{array}{l}\text { T. longipile } \\
\text { 3Sr4-2 }\end{array}$ & $4.9 \pm 0.4 \mathrm{a}$ & $2.22 \pm 0.2 \mathrm{ab}$ & $0.38 \pm 0.06 \mathrm{abc}$ & 5.8 & $5.93 \pm 0.6$ & $0.75 \pm 0.06$ \\
\hline $\begin{array}{l}\text { T. longipile } \\
\text { S1BYG }\end{array}$ & $3.3 \pm 0.2 \mathrm{bc}$ & $1.37 \pm 0.2 \mathrm{~cd}$ & $0.26 \pm 0.06 \mathrm{bcd}$ & 3.2 & $5.92 \pm 0.5$ & $0.77 \pm 0.1$ \\
\hline $\begin{array}{l}\text { T. tomentosum } \\
\text { 5Sr2-2 }\end{array}$ & $5.3 \pm 0.7$ a & $2.35 \pm 0.5 \quad \mathrm{a}$ & $0.49 \pm 0.11 \mathrm{a}$ & & $6.0 \pm 0.6$ & $0.66 \pm 0.13$ \\
\hline T. virens B19 & $2.7 \pm 0.2 \mathrm{bc}$ & $0.95 \pm 0.1 \mathrm{~d}$ & $0.16 \pm 0.03 \mathrm{~d}$ & 5.9 & $4.6 \pm 0.3$ & $0.29 \pm 0.06$ \\
\hline T. virens $\mathrm{GV} 4$ & $3.2 \pm 0.4 \mathrm{bc}$ & $1.18 \pm 0.2 \mathrm{~d}$ & $0.21 \pm 0.06 \mathrm{~d}$ & 5.6 & $3.1 \pm 0.5$ & $0.48 \pm 0.12$ \\
\hline P-value & $\mathrm{P}<0.05$ & $\mathrm{P}<0.05$ & $\mathrm{P}<0.05$ & $\mathrm{P}>0.05$ & $\mathrm{P}>0.05$ & $\mathrm{P}>0.05$ \\
\hline LSD & 1.2 & 0.8 & 0.2 & 2.19 & 3.6 & 0.5 \\
\hline
\end{tabular}

${ }^{1}$ Means followed by same letter are not different (Fisher's protected least significant different test, $\mathrm{P}<0.05)$.

\section{DISCUSSION}

Cabbage plants treated with Trichoderma longipile $6 \mathrm{Sr} 4$ and $3 \mathrm{Sr} 4-2$ and T. tomentosum $5 \mathrm{Sr} 2-2$ had greater leaf areas $(58-71 \%)$, greater shoot weights (91-102\%) and greater root weights (100-142\%) compared with the untreated plants in trial 1, after 28 days. There was no increase in the shoot:root ratios (dry weight basis) compared with the untreated plants which implies that the observed increment of shoot and root tissue weights occurred proportionately. This contradicts previous reports of increases in leaf area of petunia with an application of Trichoderma spp. being correlated with a higher shoot:root ratio (Ousley et al. 1994b). The growth promotion effect was not maintained through to the 42 day assessment and was not reproduced in trial 2 .

The inconsistency in growth promotion may be related to differences in growing conditions as indicated by growth of the untreated control plants. In trial 1, control plants grew less vigorously than in trial 2 with lower values for leaf area and shoot and root dry weights recorded. Thus, control plants in trial 1 were probably not growing to their full potential, possibly due to suboptimal conditions even though water and nutrients were not limiting.

Over the 28 day trial period, the accumulated growing degree days was similar between trials indicating a similar temperature environment. However, the total solar radiation available was only $173 \mathrm{MJ} / \mathrm{m}^{2}$ in trial 1 compared with $410 \mathrm{MJ} / \mathrm{m}^{2}$ in trial 2 . Thus, the energy available for photosynthesis in trial 1 was only half that in trial 2 and it seems likely any growth promotion effect would be more apparent in the lower light environment.

We postulate that when plants are grown under optimal conditions, expression of growth promotion is unlikely, whereas under suboptimal conditions, enhanced growth can be achieved. For example, Bjorkman et al. (1998) reported a growth promotion effect of Trichoderma in sweetcorn when low-medium vigour plants were treated, but 
not when high vigour plants were treated. Observations for field grown lettuce support this hypothesis, with increased growth of plants treated with $T$. longipile $6 \mathrm{Sr} 4$. In this situation, plants were grown under suboptimal conditions due to the presence of minor pathogens (e.g. Sclerotinia minor).

Growth promotion by Trichoderma is not species dependent. In this study, two different species ( $T$. longipile and $T$. tomentosum) gave a transient growth promotion effect and numerous other species such as T. harzianum (Chang et al. 1986; Inbar et al. 1994), T. viride (Ousley et al. 1993, 1994b) and T. koningii (Windham et al. 1986) have also been reported to promote plant growth. Similarly, within species in our study, not all isolates were capable of inducing a growth promotion effect, e.g. $T$. longipile isolate S1BYG did not show growth promotion activity. Similar results have been reported by other workers, with different strains of T. harzianum or T. viride acting differently on various host plants (Ousley et al. 1993, 1994b). Further, some Trichoderma spp. have also been reported as pathogens of maize seedlings (Edwards 1940; Falloon 1982).

\section{ACKNOWLEDGMENTS}

Dr Gary J. Samuels (Systematic Botany and Mycological Laboratory, USA) for the identification of Trichoderma isolates and the New Zealand Vegetable and Potato Growers' Federation for financial support of the field trial.

\section{REFERENCES}

Baker, R., 1988. Trichoderma spp. as plant stimulants. CRC Crit. Rev. Biotechnol. 7: 97-106.

Bjorkman, T., Blanchard, L.M. and Harman, G.E., 1998. Growth enhancement of shrunken-2 (sh2) sweet corn by Trichoderma harzianum 1295-22: effect of environmental stress. J. Am. Soc. Hort. Sci. 123: 35-40.

Chang, Y.C., Chang, Y.C., Baker, R., Kleifeld, O. and Chet, I., 1986. Increased growth of plants in the presence of the biological control agent Trichoderma harzianum. Plant Dis. 70: 145-148.

Edwards, E.T., 1940. The biological antagonism of Gibberella fujikori and Gibberella fujikori var. subglutinans to Trichoderma viride, with notes on the pathological effects of the latter fungus on maize. J. Aust. Inst. Agric. 6: 91-100.

Falloon, R.E., 1982. Fungicide seed treatment of maize to improve establishment and control seedling pathogens. N.Z. J. Exp. Agric. 10: 197-202.

Inbar, J., Abramsky, M., Cohen, D. and Chet, I., 1994. Plant growth enhancement and disease control by Trichoderma harzianum in vegetable seedlings grown under commercial conditions. Eur. J. Plant Path. 100: 337-346.

Ousley, M.A., Lynch, J.M. and Whipps, J.M., 1993. Effect of Trichoderma on plant growth: a balance between inhibition and growth promotion. Microb. Ecol. 26: 277-285.

Ousley, M.A., Lynch, J.M. and Whipps, J.M., 1994 a. Potential of Trichoderma spp. as consistent plant growth stimulators. Biol. Fertil. Soils 17: 85-90.

Ousley, M.A., Lynch, J.M. and Whipps, J.M., 1994b. The effects of addition of Trichoderma inocula on flowering and shoot growth of bedding plants. Scia Hortic. 59: 147-155.

SAS Institute Inc., 1989. SAS User's Guide. Version 6, Cary, NC: SAS Institute, Inc.

Windham, M.T., Elad, Y. and Baker, R., 1986. A mechanism for increased plant growth induced by Trichoderma spp. Phytopath. 6: 518-521. 